\title{
Low Affinity Immunoglobulin Gamma Fc Region Receptor II-B
}

National Cancer Institute

\section{Source}

National Cancer Institute. Low Affinity Immunoglobulin Gamma FC Region Receptor II-B. NCI Thesaurus. Code C38555.

Low affinity immunog lobulin gamma Fc region receptor II-b (310 aa, 34 kDa) is encoded by the human FCGR2B gene. This protein is involved in the phagocytosis of opsonized antigens. 